\title{
SPECIFIC ANTIBODY RESPONSE IN BACKYARD CHICKENS TO NEWCASTLE DISEASE THERMOSTABLE LIVE VACCINE
}

\author{
S. Baksi*, P. Puwar, N. Rao and M. Khan \\ Hester Biosciences Limited, Ahmedabad - 380006, Gujarat, India
}

\begin{abstract}
Newcastle disease (ND) is widely known poultry disease all over the world. It causes high economic losses even in backyard poultry. The purpose of present study was to estimate specific antibody response of backyard poultry chickens to thermostable vaccine of ND. Presence of antibodies before vaccination was determined by haemagglutination-inhibition (HI) test and vaccine was inoculated intraoccularly to birds of vaccinated group. Blood was withdrawn at regular intervals up to 4 months and generation of specific antibodies to the ND antigen was measured by HI test. The results showed significant increase in antibody titre at 28 days time in vaccinated birds and decrease was found after three months of vaccination in the birds. The study suggests that it is necessary to follow vaccination schedule in the backyard chickens, as they are highly susceptible to ND.
\end{abstract}

Key words: Newcastle disease, Thermostable, Backyard, Antibody, Vaccine

\section{INTRODUCTION}

Newcastle disease (ND), a poultry disease, noted by World Organisation of Animal Health, is caused by virulent avian paramyxovirus type 1 (APMV-1) strains (Jos et al., 2011). It is a disease of birds which is highly distributed throughout the world. It affects many avian species and causes significant economic loss to poultry industry (Lancaster, 1976; Spreadbrow, 1988; Cattoli et al., 2009). It is considered the most economically important avian viral disease in the world especially in developed countries due to its devastating effect on the industry (El-Yuguda and Baba, 2002; Ngaji et al., 2010; Aziz et al., 2010). The native chicken varieties adopted in free-range backyard conditions contribute about $11 \%$ of total egg production in India (Kumaresan et al., 2008). Village poultry plays a key and often undervalued role in a rural development in many poor rural households and is a global asset for many millions who live below the poverty line (Gueye, 2000). For control on disease of poultry, especially ND, vaccination has been the principal method (Okwor et al., 2013; El-Mahdy et al., 2013). Generally ND is controlled by vaccination of the flock and the infected birds are culled to prevent the spread of the disease. An effective vaccination procedure includes maintenance of cold chain transport system, holding and vaccinating individual birds properly with skilled workers/vaccinators (Nasser et al., 2000). The vaccination schedule also requires close monitoring and assurance that every bird receives vaccine properly. Control and safety of environment, feed and water supply are also essential parts of poultry farming. The selection of an ND vaccine for use in village chicken will depend on the local conditions in each country. The vaccine should be selected based on user friendliness, cost, availability, immunogenicity and thermostability and transportation facility. In countries like Africa and India, people are having village chicken in small numbers. It becomes difficult to maintain cold chain and other factors, hence is becomes highly suggestive that they use thermostable lasota vaccines (Ideris et al., 1987; Illango et al., 2005). With this background, this study was conducted with the objective to observe the effectiveness of thermostable vaccine of Hester Biosciences Limited (India) in improving protection from ND, egg production and egg quality in backyard chicken.

*Corresponding e-mail address: drsbaksi.vm@gmail.com 


\section{S. Baksi and others}

\section{MATERIALS AND METHODS}

\section{Study design}

Eighty healthy kadaknath backyard chickens of four weeks of age were selected for the study and divided into two groups: Group 1: 40 birds (vaccinated with thermostable lasota vaccine from Hester Biosciences Limited, India); Group 2: 40 birds (unvaccinated control). Birds from group 1 were kept at backyard poultry at MerdaAdraj village, Gujarat, India. Unvaccinated birds were kept at backyard poultry at Jetpura village, Gujarat, India. All birds were subjected to free supply of feed and water ad libitum and observed daily throughout study.

\section{Vaccination, blood collection and testing}

Group 1 chickens were vaccinated with one dose of thermostable lasota vaccine from Hester Biosciences Limited, India by intraocular route. Blood samples were collected from all birds at 0, 7, 14, 21, 28, 35, 42, 56, 70, 84, 98 and 112 days from chickens of both groups. Serum was separated and stored at $-20^{\circ} \mathrm{C}$. All serum samples were subjected to haemagglutination-inhibition (HI) test at Hester Biosciences Limited, Anand laboratory. Specific antibodies were measured through HI against Newcastle disease antigen (Maine Biologicals Limited, USA) by preparing 4 HA units of serum. The result was reported as $\log _{2} \mathrm{HI}$ (Abdu et al., 2012).

\section{Data analysis}

All data were entered into Microsoft Office Excel Worksheet (2007, Microsoft Corporation). The data were analyzed by single factor - analysis of variance method and $\mathrm{p}<0.05$ was considered as significant difference between the groups.

\section{RESULTS AND DISCUSSION}

Total 40 samples of group 1 and 40 samples of group 2 were collected from both villages at defined time interval and HI test was performed. Prevaccination titre at 0 days of both group 1 and 2 were 0.6 and 0.7 respectively. The $\mathrm{HI}$ titre increased gradually and found highest in vaccinated group at 28 days post collection (8.02). After 28 days, titre decreased and was reduced equivalently to 0 day level at 112 days in vaccinated group (1.02). The results of 0,28 and 112 days were significantly different as data of 28 days were compared with 0 days and that of 112 days were compared with 28 days ( $<<0.05$, Figure 1$)$. Antibody level in unvaccinated group was 0.7 at 0 day and was almost consistent throughout the study (Figure 2).

Newcastle disease virus has haemagglutinating property. Hence, HI test has been used as a standard test to measure specific antibodies against ND virus. The HI titre of 0 to 2 is generally considered negative as it produces no antibody against the virus when infected. HI value of 3 to 12 is considered as protective for chickens (Alders and Spreadbrow, 2000; Aldous, 2003). Seroprevalence of ND is found in backyard chickens all over the world (Alders et al., 1994; Chansiripornchai and Sasipreeyajan, 2006; Musako et al., 2012). In present study, birds were not infected with ND as 0 day titre of antibody was less than 2. As there are difficulties of cold chain transport and other factors, thermostable vaccines are more advantageous in backyard poultry farms in villages (Illango et al., 2005; Ritha et al., 2016). In present study also, backyard chickens were inoculated with one dose of thermostable vaccine, procured from Hester Biosciences Limited, India. The HI titre of vaccinated birds increased and reached to protective level in the duration of 7 days post vaccination. The antibody level reached to much satisfactory level significantly $(\mathrm{p}<0.05)$ after 28 days of vaccination. The titre remained at protective level up to 84 days, which suggests that vaccine may provide protection to backyard chicken up to three months post vaccination. Revaccination is suggested to the farmers after the period. 
Specific antibody response in backyard chickens

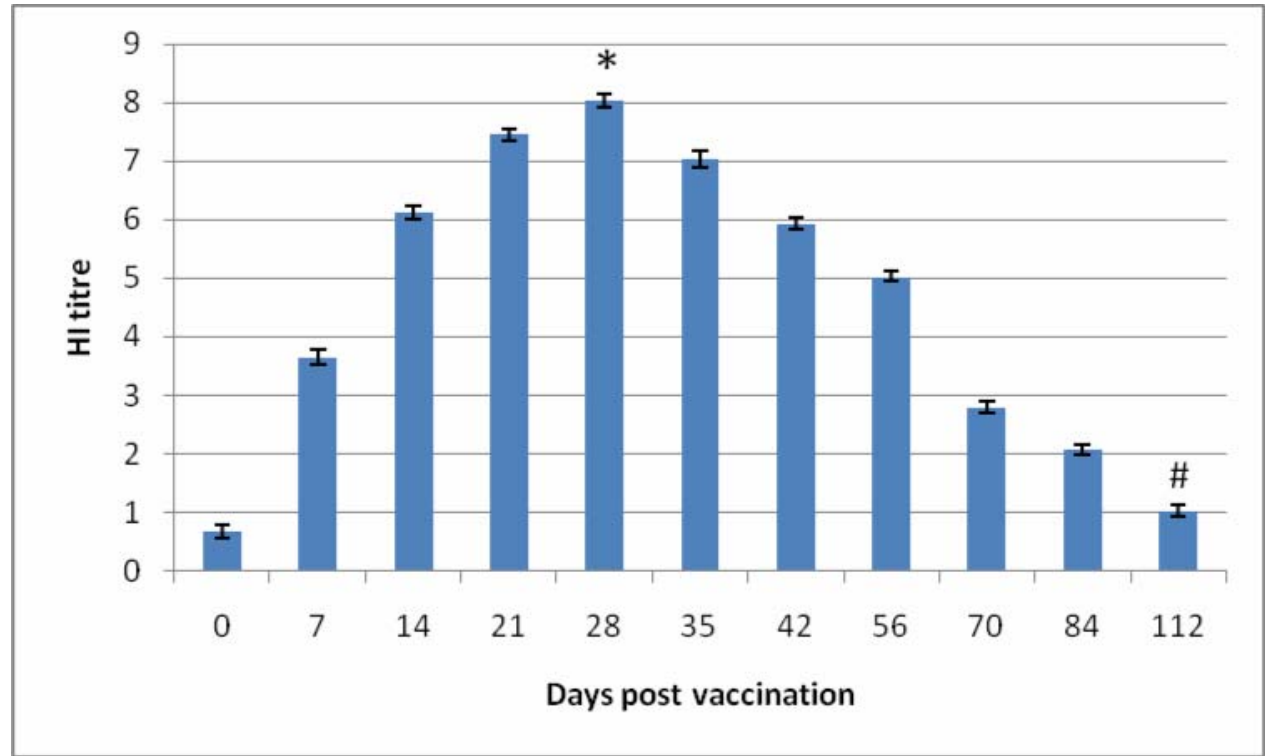

Figure 1. HI titre of group 1 (Vaccinated chickens)

The data are experssed as mean \pm SEM

${ }^{*} \mathrm{p}<0.05$, significantly different as compared to 0 days

$\# \mathrm{p}<0.05$, significantly different as compared to 28 days

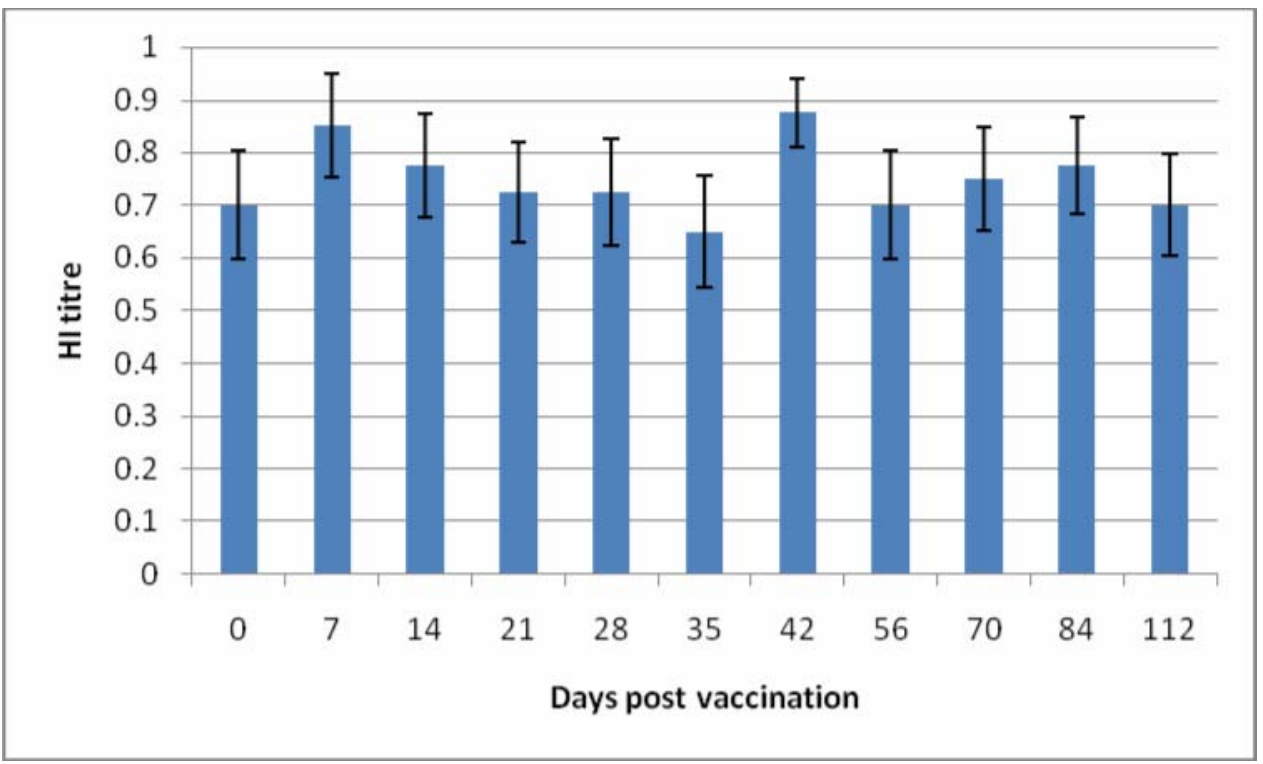

Figure 2. HI titre of group 2 (Unvaccinated chickens)

The data are experssed as mean \pm SEM 


\section{S. Baksi and others}

\section{REFERENCES}

1. Abdu P, Musa U, Joannis TM, Saidu L, Mera UM, Salami S and Haruna ES (2012). Vaccination of chicken against Newcastle disease with lasota and V4 vaccines using brans, ground grains and water as vehicles. Vom Journal of Veterinary Sciences 9: 1-10.

2. Alders R and Spradbrow P (2000). Newcastle Disease in village chickens, A field manual Maputo, Mozambique. pp. 46.

3. Alders RG, Inoue S and Katongo JC (1994). Prevalence and evaluation of Hitchner B1 and V4 vaccines for the control of Newcastle disease in village chickens in Zambia. Preventive Veterinary Medicine 21: 125-32.

4. Aldous EW, Mynn JK, Banks J and Alexander DJA (2003). Molecular epidemiological study of avian paramyxovirus type 1 (Newcastle disease virus) isolates by phylogenetic analysis of a partial nucleotide sequence of the fusion protein gene. Journal of Avian Pathology 32: 239-256.

5. Aziz AGT and Ahmed TA (2010). Serological Survey of Newcastle disease in Domestic chickens in Sulaimani Province. Journal of Zankay Sulaimani 13: 31-38.

6. Cattoli G, Fusaro A, Monne I, Molia S, LeMenach A and Maregeya B (2009). Emergence of a new genetic lineage of Newcastle disease virus in West and Central Africa - implications for diagnosis and control. Veterinary Microbiology 19: 3-4.

7. Chansiripornchai N and Sasipreeyajan J (2006). Efficacy of Live B1 or Ulster 2C Newcastle disease vaccines simultaneously vaccinated with inactivated oil adjuvant vaccine for protection of Newcastle disease virus in broiler chickens. Acta vaterinaria Scandinavica 48: 2.

8. El-Mahdy SS, Hayam F, Abd El-Wanis NA and Hamoud MM (2013). Comparative studies between different commercial types of live infectious bursal disease [IBD] vaccine strains in Egypt. American Journal of Veterinary Research 1: 113-129.

9. El-Yuguda AD and Baba SS (2002). Prevalence of selected viral infections in various age groups of village chicken in Borno state, Nigeria. Nigeria Journal Animal Production 29: 245-250.

10. Gueye EF (2000). The role of family poultry in poverty alleviation, food security and the promotion of gender equality in rural Africa. Outlook Agriculture 29: 129-136.

11. Ideris A, Ibrahim AL, Spradbrow PB and Hung Seng C (1987). Development of food pellet Newcastle disease vaccine. In: Copland JW, editor. Newcastle Disease in Poultry: A New Food Pellet Vaccine. Canberra: ACIAR pp. 20-23.

12. Illango J, Olaho MW and Mukiibi MG (2005). Immunogenicity of a locally produced Newcastle Disease I-2 thermostable vaccine in chickens in Uganda. Tropical Animal Health and Production 37: 25.

13. Jos CD, Guss K, Peter JR and Ben PP (2001). Virulence of Newcastle disease virus: What is known so far? Veterinary research 41: 122.

14. Kumaresan A, Bujarbaruah KM, Pathak KA, Chettri B, Ahmed SK and Haunshi S (2008). Analysis of a village chicken production system and performance of improved dual purpose chickens under a subtropical hill agroecosystem in India. Tropical Animal Health Production 40: 395-402.

15. Lancaster JE (1976). A history of Newcastle disease with comments on its economic effects. World Poultry Science Journal 32: 167-175.

16. Musako C and Abolnik C (2012). Determination of the seroprevalence of Newcastle disease virus (avian paramyxovirus type 1) in Zambian backyard chicken flocks. Onderstepoort Journal of Veterinary Research 79: 4.

17. Nasser M, Lohr JE, Mebratu GY, Zessin KH, Baumann MPO and Ademe Z (2000). Oral Newcastle disease vaccination trials in Ethiopia. Avian Pathology 29: 27-34.

18. Ngaji LW, Nyaga PN, Mbuthia PG, Bebora LC and Michieka JN (2010). Prevalence of Newcastle disease virus in village indigenous chickens in varied agro-ecological zones in Kenya. Livestock Research for Rural Development 22: $1-4$.

19. Okwor EC, Eze DC, Anyanwu MU, Okpe CB and Eze PC (2013). Effects of mixed vaccinations against Newcastle disease and infectious bursal disease on immune response feed consumption and weight gain in broilers. Journal of Agriculture and Veterinary Science 6: 63-68.

20. Ritha TL, Rajeshwar JJ, Harikrishnan TJ, Sukumar K, Srinivasan P and Kirubakarn JJ (2016). Studies of effectiveness of oral pellet vaccine in improving egg production and egg quality in desi chicken. Veterinary World 9: 900-903.

21. Spradbrow PB (1988). Geographical distribution. Newcastle Disease. Edited by: Alexander DJ. Kluwer Academic Publishers, Boston. pp. 247-255. 